\title{
CARDIAC AUTONOMIC ALTERATIONS IN DIFFERENT TACTICAL PROFILES OF BRAZILIAN JIU JITSU
}

ALTERAÇÕES AUTONÔMICAS CARDÍACAS EM DIFERENTES PERFIS TÁTICOS DO JIU JITSU BRASILEIRO

ALTERACIONES AUTONÓMICAS CARDÍACAS EN DIFERENTES PERFILES TÁCTICOS DEL JIU IITSU BRASILEÑO

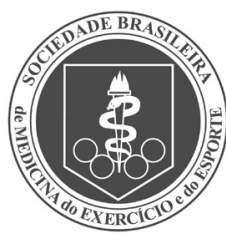

Original Article

ARTIGO ORIGINAL Artículo Original
Denner Ferreira de Sousa' (ID (Physical Education Professional) José Martins Juliano Eustaquio' (DD (Sports Physician)

Moacir Marocolo² (ID)

(Physical Education Professional)

Gustavo R. Mota'

(iD)

(Physical Education Professional)

Octávio Barbosa Neto' (ID

(Physical Education Professional)

1. Universidade Federal do Triângulo Mineiro (UFTM), Exercise Science, Health and Human Performance Research Group, Department of Sport Sciences, Institute of Health Sciences, Uberaba, MG, Brazil.

2. Universidade Federal de Juiz de Fora (UFJF), Physiology Department, Juiz de Fora, MG, Brazil.

\section{Correspondence:}

Octávio Barbosa Neto.

Universidade Federal do Triângulo Mineiro (UFTM), Exercise Science, Health and Human Performance Research Group, Department of Sport Sciences, Institute of Health Sciences. Av. Tutunas, 490, Uberaba, MG, Brazil. 38061-500. octavio.neto@uftm.edu.br; zemartinsjuliano@hotmail.com

\begin{abstract}
Introduction: Brazilian Jiu Jitsu (BJJ) is an individual sport, characterized by intermittent body movements aimed at the submission (defeat) of the opponent. The sport involves two tactical profiles of fighters: the guard $(G G)$ and the passer (PG), which present potential differences in relation to anthropometric patterns and cardiac autonomic modulation. Objectives: To evaluate the effects of different BJJ fighting styles on cardiac autonomic modulation. Methods: Twelve PG-style athletes and $12 \mathrm{GG}$-style athletes, both male, with mean ages of $30.4 \pm$ 1.9 and $30.6 \pm 1.3$ years, respectively, participated in the study. The following measurements were taken at rest: anthropometric profile, body composition and hemodynamic parameters (blood pressure [BP], basal heart rate $[\mathrm{HR}]$ and heart rate variability $[\mathrm{HRV}]$, the latter through linear and nonlinear analysis). Results: The PG fighters had higher waist and hip circumference diameters compared to the GG fighters $(p<0.05)$. There were no differences regarding baseline hemodynamic parameters of $\mathrm{HR}$ and BP. Total HRV as well as parasympathetic modulation indices in both the time and frequency domains were significantly lower in the GG fighters than in the PG fighters $(p<0.05)$. In contrast, the sympathovagal modulation markers in the frequency domain, and the sympathovagal index, were higher in $G G$ than in $P G(p<0.05)$. The SD1 index of nonlinear analysis was lower in the $G G$ fighters than in the $P G(p<0.05)$. Conclusion: In general, guardian style fighters have lower vagal modulation and cardiac sympathetic hyperactivity at rest, compared to passing fighters. Level of evidence IV; Case series.
\end{abstract}

Keywords: Sports; Sympathetic nervous system; Sports medicine; Cardiovascular system; Heart rate.

\section{RESUMO}

Introdução: O jiu jitsu brasileiro (JJB) é um esporte individual, caracterizado por movimentos corporais intermitentes, cujo objetivo é a submissão (derrota) do oponente. Nessa modalidade, há dois perfis táticos dos lutadores, o guardeiro (GG) e o passador (GP), os quais apresentam potenciais diferenças em relação aos padrões antropométricos e à modulação autonômica cardíaca. Objetivos: Avaliar os efeitos dos diferentes estilos de luta do JJB sobre a modulação autonômica cardíaca. Métodos: Participaram do estudo 12 atletas com estilo de luta GP e 12 atletas com estilo de luta $\mathrm{GG}$, ambos do sexo masculino e com idades médias de 30,4 $\pm 1,9$ e 30,6 1,3 anos, respectivamente. Foram avaliados, em repouso, o perfil antropométrico, a composição corporal e os parâmetros hemodinâmicos (pressão arterial [PA], frequência cardíaca [FC] basal e a variabilidade da frequência cardíaca [VFC], esta última através de análises lineares e não lineares). Resultados: Os lutadores do GP apresentaram maiores diâmetros da circunferência da cintura e do quadril em comparação ao $G G(p<0,05)$. Não houve diferenças em relação aos parâmetros hemodinâmicos basais da FC e da PA. A variabilidade total da FC, assim como os índices da modulação parassimpática tanto no domínio do tempo como no domínio da frequência, foram significativamente menores nos lutadores do $G G$ quando comparados aos lutadores do $G P(p<0,05)$. Em contrapartida, os marcadores da modulação simpática no domínio da frequência e o índice simpatovagal foram maiores no $G G$ em relação ao $G P(p<0,05)$. O índice SD1 da análise não linear foi menor nos lutadores do GG quando confrontados ao GP $(p<0,05)$. Conclusão: Lutadores com estilo predominantemente guardeiro apresentam menor modulação vagal e hiperatividade simpática cardíaca de repouso em comparação aos lutadores passadores. Nível de Evidência IV; Série de casos.

Descritores: Esportes; Sistema nervoso simpático; Medicina esportiva; Sistema cardiovascular; Frequência cardíaca.

\section{RESUMEN}

Introducción: El Jiu Jitsu brasileño (JJB) es un deporte individual, caracterizado por movimientos corporales intermitentes, cuyo objetivo es la sumisión (derrota) del oponente. En esta modalidad, hay dos perfiles tácticos de luchadores, el guardiero (GG) y el pasador (GP), que presentan diferencias potenciales con relación a los patrones antropométricos y a la modulación autónoma cardíaca. Objetivos: Evaluar los efectos de diferentes estilos de lucha de JJB sobre la modulación autónoma cardíaca. Métodos: Participaron en el estudio 12 atletas con estilo de lucha GP y 12 atletas con estilo de lucha GG, ambos del sexo masculino y con edades promedio de 30,4 $\pm 1,9$ y 30,6 $\pm 1,3$ años, respectivamente. Fueron evaluados, en reposo, el perfil antropométrico, la composición corporal y los parámetros hemodinámicos (presión arterial [PA], frecuencia cardíaca [FC] basal y la variabilidad de la frecuencia cardíaca [VFC], ésta última a través de análisis lineales y no lineales). Resultados: Los luchadores del GP presentaron mayores diámetros de circunferencia de cintura y cadera en comparación al $G G(p<0,05)$. No hubo diferencias con relación a los parámetros hemodinámicos basales de FC y de la PA. La variabilidad total de la FC, así como los índices de 
modulación parasimpática tanto en el dominio del tiempo como en el dominio de la frecuencia, fueron significativamente menores en los luchadores del G G cuando comparados a los luchadores del $G P(p<0,05)$. En contrapartida, los marcadores de la modulación simpática en el dominio de frecuencia y el índice simpatovagal fueron mayores en el GG con relación al GP $(p<0,05)$. El índice SD1 de análisis no lineal fue menor en los luchadores del GG cuando comparados al GP $(p<0,05)$. Conclusión: Los luchadores con estilo predominantemente guardiero presentan menos modulación vagal e hiperactividad simpática cardíaca de reposo en comparación a los luchadores pasadores. Nivel de evidencia IV; Serie de casos.

Descriptores: Deportes; Sistema nervioso simpático; Medicina deportiva; Sistema cardiovascular; Frecuencia cardíaca.

\section{INTRODUCTION}

Since ancient times, systematic fighting techniques have been developed, either for combat and self-defense purposes or as sporting activities. Known in sports as a gentle olden art, the Brazilian Jiu Jitsu (BJJ) is an individual sport characterized by the combat between two athletes who seek the submission of opponent through "chokes", "finishing,", "immobilizations" and "projections". If submission of one of the opponents does not occur, the decision is assigned to referee, which determines scores according to specific positions or punishments received during the fight ${ }^{1}$.

The characteristic of BJJ is conceived by intermittent body exercises, so that its practitioners quickly aim for their opponent's defeat ${ }^{2}$. In this sense, practitioners of this modality need a good physical condition to resist (defend) or attack successfully. The physical variables that are part of BJJ include flexibility, power, speed, strength, agility, coordination, balance and localized aerobic and muscular endurance ${ }^{3}$.

In BJJ there are two types of tactical combat profiles, the pass fighters (PFs) and guard fighters (GFs). The PFs (standing or squatting) aims to overcome the opponent's guard offensively with explosive force movements. On the other hand, the GFs (with hip on the ground) cadences the combat with lower and upper limb isometric movements ${ }^{4}$.

Thus, the acute training loads imposed due of these fighting positions differ considerably and may promote distinct autonomic and cardiovascular adaptations. So, some studies have suggested monitoring heart rate markers to assess adaptations to training types $5,6,7,8$. It is believed that the GFs develop higher levels of isometric strength production due to the constant position of dorsal decubitus to which they are chronically subjected, especially when it has its "past guard", which promotes greater pressure overload and sympathetic activity increased in cardiovascular system.

One way to assess cardiovascular autonomic modulation is by analyzing heart rate variability (HRV). This is a simple and noninvasive tool with high clinical applicability, which indirectly quantifies the modulation exerted by the sympathetic and parasympathetic nervous systems in the heart, as an auxiliary protocol for the assessment of cardiovascular stress $^{8}$. In general, training involving a larger aerobic component improves parasympathetic modulation of the heart ${ }^{9}$. However, it is evident that athletes undergoing high training volumes may present a reduction in the vagal component and an increase in sympathetic heart, leading to a decrease in athletic performance. These data suggest that cardiac sympathetic modulation may be affected by training load ${ }^{10}$.

It is interesting to observe that most cardiovascular autonomic modulation studies have mainly addressed adaptations related to sports with aerobic demand, so, little is known about adaptations to sports with anaerobic demand, such as fighting modalities. Regarding martial arts, limited investigations focus on BJJ, especially in the context of health aspects and its influence on quality of life. Currently, there is a paucity of scientific literature that emphasize the effects of different types of combat profiles of BJJ fighters in cardiovascular autonomic parameters.
Therefore, the aim of the present study was to evaluate the resting cardiac autonomic modulation in BJJ athletes, analyzing the alteration of indices of this variability as a function of different tactical combat profiles of these fighters.

\section{MATERIAL AND METHODS \\ Participants}

Twenty-four male athletes who have practiced BJJ for at least two years with $30.5 \pm 5.4$ years old and body mass index of $26.4 \pm 2.9 \mathrm{~m} /$ kg2, volunteered to participate in this study. They were allocated into two groups according to the fighting tactic: pass fighters (PFs, $n=12$ ) and guard fighters (GFs, $n=12$ ). All participants signed a free and informed consent form. Thus study was approved by the Research Ethics Committee of Federal University of Triângulo Mineiro ( $\left.n^{\circ} 1.249 .283 / 2015\right)$.

\section{Experimental design}

The study utilized a randomized cross-sectional experimental design. The data collections occurred in two sports training centers that have the BJJ modality in Uberaba city (MG). At initial time of collection, the volunteers answered a semi-structured questionnaire in the sample selection process, with criteria for range grading, combat tactical profile, experience time, training frequency, training duration, other physical exercise practice, supplementation use, medication use, steroid use, nutritional monitoring and family history of diseases. Exclusion criteria were caffeine intake six hours and diet two hours before the test, physical exercise within 24 hours and use of ergogenic nutritional and / or pharmacological resources.

\section{Anthropometric profile and body composition}

The body composition was verified through the analysis of the skinfolds by scientific Lange adipometer, with scale from 0 to $60 \mathrm{~mm}$, resolution of $1 \mathrm{~mm}$ and exerted pressure of $10 \mathrm{~g} / \mathrm{mm}^{2}$. The collected regions were the pectoralis segment (in diagonal fold between the axillary line and the nipple), the abdomen ( $2 \mathrm{~cm}$ from the umbilical scar) and the thigh (midpoint between the inguinal region and the patella border). The equation to determine skinfold thickness was established using the Jackson and Pollock protocol (skinfolds: $1.1093800-0.0008267$ [pectoral + abdominal + thigh] + 0.0000016 [pectoral + abdominal + thigh] $^{2}-0.0002574$ [age] $)^{11}$. After calculating skinfolds, it is necessary to transpose the value found into the Siri equation (fat \%: [(4.95: skinfolds) - 4.5] x 100) to find the estimated fat percentage ${ }^{12}$.

The body mass and height of the fighters were collected by mechanical scale $\left(J B^{\oplus}\right)$. Anthropometric circumferences were performed using measuring tape $\left(\right.$ Sanny $\left.{ }^{\circledR}\right)$, measuring $0.1 \mathrm{~cm}$ and total marking $2 \mathrm{~m}$.

\section{Cardiovascular parameters}

Blood pressure (BP) was noninvasively measured after 5 minutes of rest in the supine position using an automatic oscillometric cuff (M3 Intellisense HEM-7051-E; Omron Healthcare, Kyoto, Japan) with a digital 
display. Heart rate (HR) was monitored by lead II of electrocardiogram (Labchart Pro version 7.3.4, Brazil), beat-to-beat in CM5 position and analyzed by Matlab 6.1.1.450 Release 12.1.2001 software.

\section{Heart rate variability (HRV)}

HRV was performed at a stationary segment of at least 5 min of the R-wave interval (RRi) time series. The stationarity was tested by comparing the similarity of the indices obtained in the initial and final half of the chosen segment. HRV was analyzed in the time (TD) and frequency (FD) domains.

In TD, the mean standard deviation indices of all RR intervals (SDNN indicative of cardiac sympathetic modulation), square root mean square of differences between RR intervals (RMSSD) and percentage of adjacent RR intervals were calculated. duration difference greater than 50 milliseconds (pNN50), both indicative of cardiac parasympathetic modulation ${ }^{6}$.

In FD, the time series were decomposed by the autoregressive method. With this procedure, the total spectral power was calculated and the powers of each relevant spectrum component quantified (low frequency [LF $=0.04$ to $0.15 \mathrm{~Hz}$ ] and high frequency [HF $=0.15$ to 0.4 $\mathrm{Hz}]$ ). The power of each component was calculated in absolute and normalized terms (value of each component divided by the total value of the spectrum subtracted by the very low frequency component [VLF $<0.04 \mathrm{~Hz}$ ] multiplied by 100). The HF values were considered as indicative of cardiac parasympathetic modulation, while the normalized LF value was interpreted mainly as a result of cardiac sympathetic modulation. The LF/HF ratio was considered as the cardiac sympathovagal balance ${ }^{13}$.

\section{Statistical analysis}

The normality of data distribution was analyzed by the Shapiro-Wilk test. The unpaired Student's t test or the Mann-Whitney test was used to compare the groups (GFs and PFs). Values of $p<0.05$ were considered significant. Data are presented as mean \pm SE.

\section{RESULTS}

Both groups presented similar characteristics and body composition (Table 1). Regarding the anthropometric profile, the fighters with the pass tactical fight style showed higher waist and hip circumference diameters compared to the guard fighters ( $p<0.05$ ).

Baseline characteristics of hemodynamic parameters are shown in Figure 1, no significant differences were observed in the resting heart rate of guard fighters ( $64.3 \pm 1.1 \mathrm{bpm})$ when compared to pass fighters (62.4 \pm 0.9 bpm; $p=0.505$ ) (Figura 1A), as well as the baseline systolic (127.9 $\pm 1.7 \mathrm{mmHg}$ in GFs vs. $123.8 \pm 2.7 \mathrm{mmHg}$ in PFs; $p=0.214$ ) (Figura 1B), diastolic (80.7 $\pm 0.7 \mathrm{mmHg}$ in GFs vs. $79.7 \pm 0.9 \mathrm{mmHg}$ in PFs; $p=0.418$ ) (Figura 1C) and mean blood pressure ( $96.4 \pm 0.7 \mathrm{mmHg}$ in GFs vs. 94.4 $\pm 1.2 \mathrm{mmHg}$ in PFs; $\mathrm{P}=0.170$ ) (Figura 1D).

Regarding the heart rate variability index (Table 2), the TD total variance index was significantly higher in the guard fighters when compared to the pass style fighters ( $p<0.05$ ). In contrast, the RMSSD and pNN50 index (both markers of cardiac parasympathetic modulation in TD) were significantly lower in guard fighters group compared to pass fighters group ( $p<0.05$ ). When analyzing the FD indexes, the spectrum of the LF band component (marker of cardiac sympathetic modulation) was higher in GFs than PFs ( $p<0.05)$. Similar result was observed in LF/HF ratio components (marker of sympathovagal balance over the heart), which was also higher in the guard style fighters ( $p<0.005)$. On the other hand, the spectrum of the HF band component (marker of cardiac parasympathetic modulation) was reduced in the guard fighters group $(p<0.05)$. The SD1 index, which assesses vagal activity by nonlinear method of heart rate variability, is also reduced in guard fighters $(p<0.05)$.
Table 1. Anthropometric profile and body composition of BJJ athletes with different fighting styles evaluated in the study. Values are presented as mean \pm standard error of the mean (epm), median values (25.75 and percentiles).

\begin{tabular}{|c|c|c|c|}
\hline & $\begin{array}{l}\text { Guard Fighters } \\
\qquad(n=12)\end{array}$ & $\begin{array}{l}\text { Pass Fighters } \\
\qquad(n=12)\end{array}$ & $p$ \\
\hline Age (years) & $30.4 \pm 1.9$ & $30.6 \pm 1.3$ & 0.940 \\
\hline BJJ Practice Time (years) & $11.8 \pm 3.1$ & $9.7 \pm 2.5$ & 0.723 \\
\hline Weight (kg) & $84.5 \pm 3.9$ & $85.6 \pm 1.9$ & 0.798 \\
\hline Height (cm) & $179.0[177.0-180.0]$ & $175.0[173.2-179.0]$ & 0.075 \\
\hline $\mathrm{BMI}\left(\mathrm{kg} / \mathrm{m}^{2}\right)$ & $26.8 \pm 0.5$ & $27.1 \pm 0.9$ & 0.842 \\
\hline Fat Percentage (\%) & $22.8 \pm 2.2$ & $25.3 \pm 1.5$ & 0.357 \\
\hline Muscle Mass (kg) & $64.6 \pm 2.1$ & $63.8 \pm 1.5$ & 0.782 \\
\hline Fat Mass (kg) & $19.9 \pm 2.7$ & $21.8 \pm 1.5$ & 0.548 \\
\hline $\operatorname{Neck}(\mathrm{cm})$ & $40.5 \pm 0.8$ & $40.8 \pm 0.7$ & 0.761 \\
\hline Pectoralis $(\mathrm{cm})$ & 100.0 [95.1-105.7] & 99.0 [97.1-101.0] & 0.761 \\
\hline Right Arm (cm) & $33.0[31.8-35.0]$ & $32.7[31.2-33.7]$ & 0.429 \\
\hline Left Arm (cm) & $34.0[31.3-34.7]$ & $30.5[30.0-31.7]$ & 0.056 \\
\hline Right Forearm $(\mathrm{cm})$ & $30.7 \pm 0.3$ & $30.2 \pm 0.4$ & 0.412 \\
\hline Left Forearm $(\mathrm{cm})$ & $29.5 \pm 0.8$ & $28.8 \pm 0.4$ & 0.681 \\
\hline Right Thigh (cm) & $55.0[52.5-58.1]$ & $59.5[55.6-60.0]$ & 0.146 \\
\hline Left Thigh (cm) & $56.5[52.6-58.5]$ & $58.0[55.2-59.7]$ & 0.525 \\
\hline Right Leg $(\mathrm{cm})$ & $39.5[34.5-40.7]$ & $37.0[34.0-39.1]$ & 0.440 \\
\hline Left Leg (cm) & $39.0[34.1-41.0]$ & $37.0[37.0-38.7]$ & 0.494 \\
\hline Waist (cm) & $84.1 \pm 1.0$ & $91.0 \pm 1.3$ & 0.001 \\
\hline Abdomen $(\mathrm{cm})$ & $87.8 \pm 1.5$ & $91.7 \pm 1.3$ & 0.105 \\
\hline $\mathrm{Hip}(\mathrm{cm})$ & 100.0 [98.2-101.0] & $106.0[102.0-106.0]$ & 0.020 \\
\hline Waist/Hip Ratio (cm) & $0.85 \pm 0.01$ & $0.87 \pm 0.01$ & 0.221 \\
\hline
\end{tabular}
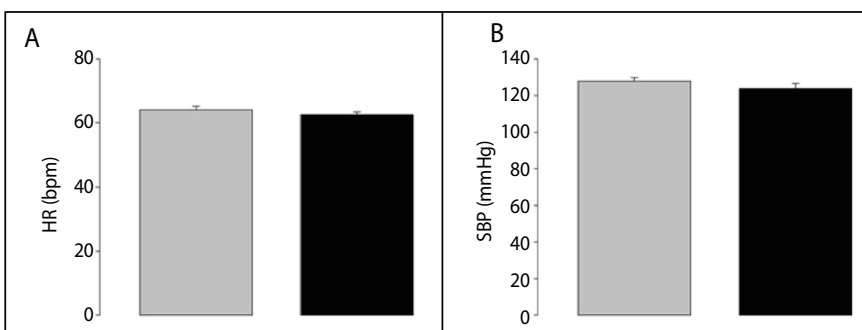

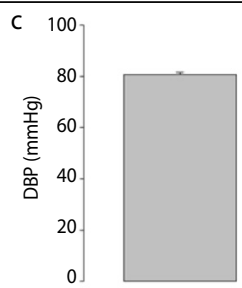

GFS

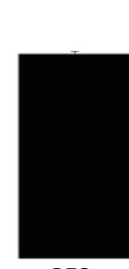

PFS

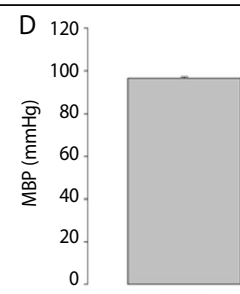

GFS

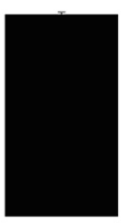

PFS
GFs: Guard Fighters; PFs: Pass Fighters. Values are presented as mean \pm standard error of the mean (epm).

Figure 1. Baseline hemodynamic parameters of BJJ athletes with different fighting styles, heart rate $(1 \mathrm{~A})$, systolic blood pressure $(1 \mathrm{~B})$, diastolic blood pressure $(1 \mathrm{C})$ and mean blood pressure (1D).

\section{DISCUSSION}

The main findings of this study were that BJJ athletes with predominance of guard tactical profile showed, in relation to the fighters with pass tactical style, cardiac alterations represented by reduced frequency variability, attenuated vagal activity and high sympathetic modulation.

Chronic aerobic exercises are effective in controlling and / or increasing heart rate variability, mainly because they cause increased of cardiac vagal modulation ${ }^{14,15}$. However, this cardioprotective effect of exercise training on autonomic function seems to be associated with the modality of exercise ${ }^{15,16,17}$. The fighters evaluated in our study practice BJJ, which is characterized as a fighting sport with anaerobic predominance, coupled with considerable strength recruitment and 
Table 2. Heart rate variability indexes measured in BJJ athletes with different style fighting.

\begin{tabular}{c|c|c|c}
\hline & $\begin{array}{c}\text { Guard Fighters } \\
(\mathbf{n}=\mathbf{1 2})\end{array}$ & $\begin{array}{c}\text { Pass Fighters } \\
(\mathbf{n}=\mathbf{1 2})\end{array}$ & $\mathbf{p}$ \\
\hline RR interval (ms) & $892.8 \pm 11.0$ & $891.3 \pm 17.6$ & 0.944 \\
\hline Total Variance $\left(\mathrm{ms}^{2}\right)$ & $1961.9 \pm 264.2$ & $3112.9 \pm 387.6$ & 0.022 \\
\hline SDNN (ms) & $56.6 \pm 7.2$ & $51.1 \pm 3.6$ & 0.579 \\
\hline RMSSD (ms) & $30.3 \pm 2.7$ & $47.7 \pm 4.7$ & 0.003 \\
\hline pNN50 (\%) & $19.8[12.5-26.8]$ & $41.2[33.1-60.3]$ & 0.003 \\
\hline VLF $\left(\mathrm{ms}^{2}\right)$ & $578.3 \pm 78.5$ & $589.3 \pm 56.1$ & 0.921 \\
\hline LF $\left(\mathrm{ms}^{2}\right)$ & $877.2 \pm 44.2$ & $639.9 \pm 47.1$ & 0.003 \\
\hline LF $(\mathrm{nu})$ & $53.0 \pm 2.9$ & $43.6 \pm 5.8$ & 0.132 \\
\hline HF $\left(\mathrm{ms}^{2}\right)$ & $464.4[328.9-571.5]$ & $514.0[470.4-531.6]$ & 0.469 \\
\hline HF $(\mathrm{nu})$ & $43.0 \pm 2.5$ & $58.1 \pm 3.4$ & 0.002 \\
\hline LF/HF & $1.9[1.6-2.2]$ & $1.1[1.0-1.4]$ & 0.037 \\
\hline SD1 $(\mathrm{ms})$ & $25.9 \pm 1.8$ & $34.4 \pm 1.2$ & 0.005 \\
\hline SD2 (ms) & $57.1 \pm 5.6$ & $70.9 \pm 4.9$ & 0.108 \\
\hline SD1/SD2 & $0.48 \pm 0.03$ & $0.49 \pm 0.03$ & 0.805 \\
\hline
\end{tabular}

Values are expressed as mean \pm standard error of the mean (epm), median values (25.75 and percentiles). SDNN: Standard deviation of the average of all RR intervals; RMSSD: Square root mean square of the differences between RR intervals; pNN50: Percentage of adjacent RR intervals with duration difference greater than 50 milliseconds; VLF: Very low frequency; LF: Low Frequency; HF: High frequency; LF/HF: sympathovagal relationship; nu: normalized units; SD1: standard deviation of instantaneous beat-by-beat variability; SD2: Long-term standard deviation of continuous R-R intervals.

high isometric component. This fact could partly explain our findings, that is, the reason because the guard fighters exhibited attenuated resting cardiac vagal activity.

Usually, the pass style fighters are stronger and / or heavier who benefit from this biotype to generate greater mechanical overload on their opponent. On the other hand, the guard fighters are generally larger fighter and more flexible, with advantages for applying levers from the strength of the opponent, and thus they perform the isometric force for a longer time of fight.

The literature is scarce regarding the changes produced in cardiac autonomic modulation due to the usual practice of BJJ. Previous study did not show any change in HRV spectral measurements in BJJ fighters compared to sedentary individuals, and the authors demonstrated that BJJ training is not associated with changes in cardiovascular autonomic modulation in any of the training periodization phases ${ }^{19}$.

In the practice of strength exercises with high isometric component, cardiac sympathetic modulation remains high, while parasympathetic modulation is lower ${ }^{20,21}$, which may increase the risk of acute cardiovascular events ${ }^{22}$. Strength exercises (including BJJ) promote increased sympathetic modulation and attenuation of cardiac parasympathetic modulation, especially in the most intense fight ${ }^{23}$.

While it is important to understand how different factors of strength training can alter autonomic responses, many of these training had not been documented. As an example, the type of muscle contraction may alter autonomic modulation. During isometric exercise, sympathetic activity is driven by the amount of muscle mass used. In this context, this fact can be transposed to the guard position in the BJJ, where this fighting style causes a high recruitment of muscle groups, which chronically may affect the intrinsic control of sympathetic modulation ${ }^{24}$.

Cardiac autonomic dysfunction is characterized in part by a decrease in cardiac vagal modulation 25,26 , which may provoke the onset and aggravate the prognosis of cardiovascular disease ${ }^{27}$. In fact, cardiac vagal impairment, detected by reduced parasympathetic modulation, is a marker of cardiac electrical instability and has been shown to be an independent prognostic factor for ventricular arrhythmias and sudden death. In the clinical scenario, sudden death resulting from cardiac arrhythmias is an important cause of mortality ${ }^{28}$. The onset of large arrhythmias is generally considered an unpredictable phenomenon, often associated with the presence of cardiovascular risk factors.

It was also evidenced in our study that the guard fighters have a greater cardiac sympathetic modulation in the rest situation. The performance of strength exercises (including BJJ) is known to promote changes in cardiac autonomic modulation, which remain for a long period after the end of the session ${ }^{23,29}$.

High levels of sympathetic activity are present in several cardiovascular diseases (such as acute myocardial infarction, chronic congestive heart failure and hypertension), and are reinforced by the dysregulation of control pathways and central integration of autonomic balance 30 . In addition, several academic reports demonstrate that sympathetic hyperactivity plays an important role in the genesis and progression of hypertension and target organ damage. The mechanisms involved in the blood pressure response were not studied in the present study. However, it can be predicted that in the strength exercise session, there may possibly be a greater reduction in venous return, disabling the cardiopulmonary receptors ${ }^{20}$.

It is interesting to note that, although greater cardiac sympathetic modulation was observed in the guard fighters (represented by the higher LFnu spectral band indexes and the LF / HF component ratio), these values are not considered exacerbated in the context of the clinical aspect in respect to cardiovascular health. However, more research is needed, with consistent evidence to better understand this topic.

\section{CONCLUSION}

BJJ athletes with predominance of guard fight style exhibit lower vagal modulation and resting cardiac sympathetic hyperactivity compared to pass fighters.

All authors declare no potential conflict of interest related to this article

AUTHORS' CONTRIBUTIONS: Each author made significant individual contributions to this manuscript. DFS: writing, revision and performing the anthropometric measures and cardiac autonomic modulation variables; JMJE: analysis of the data and writing; MM: statistical analysis and bibliographic review; GRM: intellectual concept, review and performing the anthropometric measurements and cardiac autonomic modulation variables; OBN: writing, review and preparation of the entire research project. All the authors reviewed and approved the final version of the manuscript.

\section{REFERENCES}

1. Takahashi R. Plyometrics: power training for judo - plyometric training with medicine balls. National Strength Cond Assoc J. 1992;14(2):66-71.

2. Scarpi MJ, Conte M, Rossin RA, Skubs R, Lenk RE, Brant R. Associação entre dois diferentes tipos de estrangulamento com a variação da pressão intraocular em atletas de jiu-jitsu. Arq Bras Oftalmol. 2009;72(3):341-5.

3. Andreato LV, Julio UF, Panissa VL, Esteves JV, Hardt F, Moraes SM, et al. Brazilian Jiu-Jitsu Simulated Competition Part I. J Strength Cond Res. 2015;29(9):2538-49.

4. Báez E, Franchini E, Ramírez-Campillo R, Cañas-Jamett R, Herrera T, Burgos-Jara C, et al. Anthropometric characteristics of top-class Brazilian Jiu Jitsu athletes: Role of fighting style. Int J Morphol. 2014;32(3):1043-50.

5. Garet M, Tournaire N, Roche F, Laurent R, Lacour JR, Barthélémy JC, et al. Individual Interdependence between nocturnal ANS activity and performance in swimmers. Med Sci Sports Exerc. 2004:36(12):2112-18.
6. Borresen J, Lambert MI. Autonomic control of heart rate during and after exercise: measurements and implications for monitoring training status. Sports Med. 2008;38(8):633-46.

7. Hartwig TB, Naughton G, Searl J. Load, stress, and recovery in adolescent rugby union players during a competitive season. J Sports Sci. 2009;27(10):1087-94

8. Mazon J, Gastaldi A, Di Sacco T, Cozza I, Dutra S, Souza H. Effects of training periodization on cardiac autonomic modulation and endogenous stress markers in volleyball players. Scand J Med Sci Sports. 2013;23(1):114-20.

9. Borresen J, Lambert MI. Autonomic control of heart rate during and after exercise: measurements and implications for monitoring training status. Sports Med. 2008;38(8):633-46.

10. Lee CM, Mendoza A. Dissociation of heart rate variability and heart rate recovery in well-trained athletes. Eur J Appl Physiol. 2012;112(7):2757-66. 
11. Jackson AS, Pollock ML. Generalized equations for predicting body density of men. Br J Nutr. 1978;40:497-504

12. Siri WE. Body composition from fluid spaces and density: analysis of methods. In: Brozeck J, Henschel A. Techniques for measuring body composition. Washington, DC: National Academy of Science. 1961;233-244.

13. Heart rate variability: standards of measurement, physiological interpretation and clinical use. Task Force of the European Society of Cardiology and the North American Society of Pacing and Electrophysiology. Circulation. 1996;93(5):1043-65.

14. Sztajzel J, Jung M, Sievert K, Luna AB. Cardiac autonomic profile in different sports disciplines during all-day activity. J Sports Med Phys Fitness. 2008;48(4):495-501.

15. Collier SR, Kanaley JA, Carhart R Jr, Frechette V, Tobin MM, Bennett N, et al. Cardiac autonomic function and baroreflex changes following 4 weeks of resistance versus aerobic training in individuals with pre-hypertension. Acta Physiol (Oxf). 2009;195(3):339-48.

16. Perez-Quilis C, Kingsley JD, Malkani K, Cervellin G, Lippi G, Sanchis-Gomar F. Modulation of Heart Rate by Acute or Chronic Aerobic Exercise. Potential Effects on Blood Pressure Control. Curr Pharm Des. 2017;23(31):4650-57.

17. D'Agosto T, Peçanha T, Bartels R, Moreira DN, Silva LP, Nóbrega AC, et al. Cardiac autonomic responses at onset of exercise: effects of aerobic fitness. Int J Sports Med. 2014;35(10):879-85.

18. Buchheit M, Gindre C. Cardiac parasympathetic regulation: respective associations with cardiorespiratory fitness and training load. Am J Physiol Heart Circ Physiol. 2006;291(1):451-8.

19. Rezende RA, Santos DA, Silva Jr ND, Forjaz CL, Tinucci T. Fase do treinamento esportivo não afeta a variabilidade da frequência cardíaca em atletas de jiu-jitsu. Rev Soc Cardiol Estado de São Paulo. 2013;23(Suppl 3A):21-5.

20. Kingsley JD, Panton LB, McMillan V, Figueroa A. Cardiovascular autonomic modulation after acute resistance exercise in women with fibromyalgia. Arch Phys Med Rehabil. 2009;90(9):1628-34.

21. Heffernan KS, Kelly EE, Collier SR, Fernhall B. Cardiac autonomic modulation during recovery from acute endurance versus resistance exercise. Eur J Cardiovasc Prev Rehabil. 2006;13(1):80-6.

22. Seiler S, Haugen O, Kuffel E. Autonomic recovery after exercise in trained athletes: intensity and duration effects. Med Sci Sports Exerc. 2007;39(8):1366-73.

23. Lima AHA, Forjaz CL, Silva GQ, Menêses AL, Silva AJ, Ritti-Dias RM. Acute effect of resistance exercise intensity in cardiac autonomic modulation after exercise. Arq Bras Cardiol. 2011;96(6):498-503.

24. Seals DR. Influence of muscle mass on sympathetic neural activation during isometric exercise. J Appl Physiol (18985). 1989;67:1801-6.

25. Kleiger RE, Miller JP, Bigger Jr JT, Moss AJ. Decreased heart rate variability and its association with increased mortality after acute myocardial infarction. Am J Cardiol. 1987;59(4):256-62.

26. Ricardo DR, Almeida MB, Franklin BA, Araújo CG. Initial and final exercise heart rate transients: influence of gender, aerobic fitness, and clinical status. Chest. 2005;127(1):318-27.

27. Chumaeva N, Hintsanen M, Hintsa T, Ravaja N, Juonala M, Raitakari OT, et al. Early atherosclerosis and cardiac autonomic responses to mental stress: a population-based study of the moderating influence of impaired endothelial function. BMC Cardiovasc Disord. 2010;10:16.

28. Vanberg P, Atar D. Androgenic anabolic steroid abuse and the cardiovascular system. Handb Exp Pharmacol. 2010;(195):411-57.

29. Holt AC, Plews DJ, Oberlin-Brown KT, Merien F, Kilding AE. Cardiac parasympathetic and anaerobic performance recovery after high intensity exercise in rowers. Int J Sports Physiol Perform. 2018;14(3):331-8.

30. Herring N, Paterson DJ. Neuromodulators of peripheral cardiac sympatho-vagal balance. Exp Physiol. 2009:94(1):46-53. 